\title{
Study on pregnant teenagers referred by Obstetricians for medico-legal examination
}

$M_{\text {Vidanapathirana }}{ }^{*}$, RHAI Rathnaweera ${ }^{2}, K_{R}$ Munasinghe ${ }^{3}$, LKG Sanjeewanee $^{3}$

${ }^{1}$ Department of Forensic Medicine, Faculty of Medical Sciences, University of Sri Jayewardenepura

${ }^{2}$ Office of the Judicial Medical Officer, Galle

${ }^{3}$ Department of Forensic Medicine, Faculty of Medicine, Galle

*Corresponding author: Tel:0718244641. E-mail address: mudithavidana@yahoo.co.uk

Introduction: Teenage pregnancy is defined as pregnancy in girls of age 19 or younger. Mandatory reporting of all pregnant teenagers to police by the Obstetricians seems to come into conflict with the best interest principle in the management of children.

Objective: To explore and explain the phenomenon of teenage pregnancy and the implications of such incidents

Methodology: A descriptive cross-sectional study of all pregnant teenagers who were referred by Obstetricians from June 2009-June 2010 to Faculty of Medicine, Galle, were included.

Results: Number of pregnant teenagers was 19. Ten were 'living together' with their 'husbands'. Case conferences were conducted in all cases. One teenage mother was sent to a home for pregnant mothers until delivery. Three delivered babies were handed over to probationary homes and other delivered babies were handed over to teenage mothers them selves under the supervision of the probation officers.

Conclusions: Majority of pregnant teenagers were 'living together' with their 'husbands'. Having to undergo interrogations by the police due to mandatory reporting of all the teenage pregnancies to police by the Obstetricians may inhibit pregnant teenagers seeking treatment from qualified medical personnel which in turn may lead victims to seek treatment from quacks putting their lives in danger. The offences which are legally required to be reported to police mentioned in section 21 of the Criminal Procedure Code of Sri Lanka, do not include rape or teenage pregnancy. Therefore, unless otherwise indicated, for the best interest of the children involved, it is sufficient to hold an institutional case conference with regard to teenage pregnancies.

Keywords: Teenage pregnancy, Obstetricians, medico-legal examination

\section{Introduction}

Teenage pregnancy is defined as pregnancy in girls of age 19 or younger[1]. Mandatory reporting of all pregnant teenagers to police by the Obstetricians seems to come into conflict with the best interest principle in the management of children in many occasions. At the same time, for non-reporting of teenage pregnancies to police, few members of the ministry of health have been summoned to courts in the recent past[2]. According to the 


\section{General objective}

To explore and explain the phenomenon of teenage pregnancy and the implications of such incidents

\section{Specific objectives}

1. To explain the characteristics of teenage pregnancies.

2. To identify factors important for policy making with regard to mandatory reporting of them to police.

\section{Methodology}

Study type: A descriptive cross-sectional study

Study population: All the pregnant teenagers, referred to the Department of Forensic Medicine, Faculty of Medicine, Galle, from June 2009- June 2010 were included in the study.

Data collection and analysis: An interviewer administered questionnaire and face-to-face interviews were used to interview all the pregnant teenagers and their parents or guardians after obtaining informed consent. A case conference was conducted in all cases. All data of different variables were coded appropriately and entered to a computer using Microsoft Excel program and were analysed by using SPSS package.

Ethical considerations: Ethical approval was taken from the ethics review committee of the Faculty of Medicine, Galle before starting the study.

\section{Results}

There were 19 pregnant teenagers. Out of them 9 were 'living together' with 'husband' and one was illegally 'married'. They were living either with her mother or her mother in law. Eleven pregnant teenagers belonged to nuclear families and 8 were from extended families. Four were from urban areas and 15 were from rural areas.
Twelve fathers of the pregnant teenagers used to take alcohol regularly. One mother was addicted to drugs. Two parent families were divorced and 2 were in the second marriage.

None of the pregnant teenagers were less than 14 years of age. Two were 14 years, 3 were 15 years, 5 were 16 years, 7 were 17 years and 2 were 18 years. Five incidents had taken place at home and 14 out side.

Ten perpetrators were 'husbands', 5 were boy friends and 4 were relatives.

Case conferences were conducted in all cases. One teenage mother was sent to a home for pregnant mothers (Ma-Sevana) until delivery. Three delivered babies were handed over to probationary homes and other delivered babies were handed over to teenage mothers them selves under the supervision of the probation officers.

\section{Discussion and conclusions}

The medico-legal duties of the Teaching Hospital Karapitiya (THK) are equally divided among the staffs of the Office of the JMO, THK and the academic staff of the, Department of Forensic Medicine (DFM), Faculty of Medicine, Galle. Assuming similar rate of referring to the Office of the JMO too, this would have been about 40 pregnant teenagers reported during the period of study.

In the Indian subcontinent, particularly in rural regions where the rate of teenage pregnancy is much higher than it is in urbanized areas[1]. Majority of pregnant teenagers in this study were from nuclear families living in rural areas. In the families of pregnant teenagers, majority of fathers were taking alcohol regularly and a significant number of families was either divorced or in their second marriage. Majority of the victims were between 16-17 years of age. Study done by Dissanayake (2008) also showed the number of victims increases with age from 13 to $18[4]$. 
Majority of said incidents had taken place outside the home and perpetrated by nonrelatives. Considerable number of perpetrators was 'husbands' or boy friends. Majority of pregnant teenagers were living together with their 'husbands'. Further, a significant number of these pregnancies are not a sequalae of 'sexual abuse'. In rural setups such 'marriage' or 'living together' are arranged with the consent of the parents[4]. According to the personal experience of the researchers, some cult groups (eg. Gypsies) traditionally get married at a very early age and due to mandatory reporting to police, the 'husbands' and wives are separated for a considerable period of time.

The section 5 (2) of the act No.56, the International Convention on Civil and Political Rights (ICCPR)[5] of Sri Lanka (2007) decrees that in all matters concerning children, whether undertaken by public or private social welfare institutions, courts, administrative authorities or legislative bodies, the best interest of the child shall be of paramount importance. 'Best interests of the child' is the doctrine used by most courts to determine a wide range of issues relating to the well-being of children[6].

Having to undergo interrogation by the police due to mandatory reporting of all teenage pregnancy by the Obstetricians may inhibit pregnant teenagers seeking treatment from qualified medical personnel which in turn may lead victims to seek treatment from quacks putting their lives in danger. Teenage pregnancies, especially those below 17 years of age, have a significantly higher risk of adverse outcomes[7]. A study done in the estate sector in Sri Lanka in 2008 on such pregnancies revealed that a substantial number of them are subjected to criminal abortions[4].

The offences which are required legally to be reported to police mentioned in section 21 of the Criminal Procedure Code of Sri Lanka[8], do not include rape or teenage pregnancy[9]. Therefore, unless otherwise indicated, for the best interest of the children involved, it is sufficient to hold an institutional case conference with regard to teenage pregnancies. Importance of the conduction of case conferences to protect the best interests of the children in all cases of pregnant teenagers should also be highlighted here.

A pregnancy in a teenager itself is a burden to a family of the child. The litigations arising from indiscriminate reporting of all teenage pregnancies to the police make such burden worse.

\section{Recommendation}

We believe that the College of Forensic Pathologist of Sri Lanka should take initiative to formalize the procedure of reporting pregnant teenagers to police for medico-legal purposes in order to safeguard the best interest of the child victims.

The decision to report to police should be taken on case by case basis after taking a holistic view on all aspects of each teenage pregnancy separately.

\section{References}

1. Banerjee, B., Pandey, G., Dutt, D., Sengupta, B., Mondal, M., Deb, S. Teenage Pregnancy: A Socially Inflicted Health Hazard. Indian Journal of Community Medicine, 2009, 34(3), 227-231.

2. Official meeting held on $13^{\text {th }}$ December 2010 at the Ministry of Health, on 'seeking advice with regard to teenage pregnancy and provision of health care services'.

3. Parliament of the democratic socialist republic of Sri Lanka. Marriage registration 
(amendment) act No.18 of 1995, Department of Government Printing, Sri Lanka.

4. Dissanayake L. Teenage pregnancies in the Estate Sector. Colombo University Community Extension Center. September 2008.

http://www.fpasrilanka.org/downloads/Tee nage (accessed on 02.02.2011)

5. Parliament of the democratic socialist republic of Sri Lanka. International convention on civil and political rights (ICCPR) act, No. 56 of 2007, Department of Government Printing, Sri Lanka, p.4.

6. Wikipedia. The Free Encyclopedia. http://dictionary.babylon.com/best_interes t_of_the_child/\#encyclopedia (accessed on 31.01.2011)

7. Goonewardene IM, Deeyagaha Waduge RP. Adverse effects of teen pregnancy. Ceylon Med J. 2005 Sep; 50(3):116-20

8. Parliament of the democratic socialist republic of Sri Lanka. Code of Criminal Procedure act no.15 of 1979. Department of Government Printing, Sri Lanka, p.12.

9. Personal communication with Mr. Palitha Fernando, the Additional Solicitor General of Sri Lanka.

\section{Author Contribution}

Design to the study - MVP, RHIR

Supervision to the study- MVP

Analysis of the data- MVP,RHAIR,KRM,LKGS

Interpretation of the results-MVP

Writing the manuscript - MVP

Revising the manuscript- MV 